\title{
Evaluation of the Radioprotective Effects of Propolis and Flavonoids in Gamma-Irradiated Mice: The Alkaline Comet Assay Study
}

\author{
Vesna Benković, ${ }^{*}, a$ Nada Orsolić, ${ }^{a}$ Anica Horvat Knežević, ${ }^{a}$ Snježana Ramić,,${ }^{b}$ Domagoj Đikićc, ${ }^{a}$ \\ Ivan BAŠÍc, ${ }^{a}$ and Nevenka KOPJAR ${ }^{c}$ \\ ${ }^{a}$ Department of Animal Physiology, Faculty of Science, University of Zagreb; Rooseveltov trg 6, HR-10000 Zagreb, \\ Croatia: ${ }^{b}$ University Hospital for Tumors; HR-10000 Zagreb, Croatia: and ${ }^{c}$ Institute for Medical Research and \\ Occupational Health; Ksaverska cesta 2, HR-10000 Zagreb, Croatia. \\ Received June 16, 2007; accepted October 18, 2007
}

The radioprotective effects of water-soluble derivate of propolis (WSDP) collected in Croatia, and single flavonoids, caffeic acid, chrysin and naringin in the whole-body irradiated CBA mice were investigated. Irradiation was performed using a $\gamma$-ray source $\left({ }^{60} \mathrm{Co}\right)$, and absorbed doses were 4 and $9 \mathrm{~Gy}$. The efficiency of test components was evaluated when given intraperitoneally (i.p.) at dose of $100 \mathrm{mg} \mathrm{kg}^{-1}$ for 3 consecutive days before and/or after irradiation. Moreover, possible genotoxic effects of all test components were assessed on non-irradiated animals. The higher efficiency of test components was observed when given preventively. The results suggest that propolis and related flavonoids given to mice before irradiation protected mice from lethal effects of wholebody irradiation and diminish primary DNA damage in their white blood cells as detected by the alkaline comet assay.

Key words radioprotection; propolis; flavonoid; mouse; alkaline comet assay

Ionizing radiation is classified as a potent carcinogen. When interacting with living cells, it causes a variety of changes depending on exposed and absorbed dose, duration of exposure and interval after exposure, and susceptibility of tissues. ${ }^{1)}$ It is well established that ionizing radiation by direct ionization and through generation of toxic free radicals causes single strand breaks, double strand breaks, oxidative damage to sugar and base residues, chromosomal aberration and mutation. ${ }^{2)}$

Since the radiation effects are not discriminate, transient and/or permanent injury to normal tissues and cells are unavoidable. ${ }^{3)}$ Efforts to reduce toxicity to normal tissue cells and organs have led to the search for cytoprotective agents. Unfortunately, most of chemical radioprotectors (AET, WR 2721, WR 1065) have shown toxic side effects that limit their use in medical practice. ${ }^{4)}$ Investigations for effective and non toxic compounds with radioprotection capability led to increasing interest in naturally occurring antioxidants.

Propolis is adhesive resinous substance manufactured by honey bees from leaf, bud and sap of trees and flower blossoms. Major constituents of propolis are flavonoids, organic acids, phenols, various kinds of enzymes, vitamins and minerals. $^{5,6)}$ Because of its broad spectrum of biological properties the interest in propolis as harmless medicine has been increased. ${ }^{7)}$ Propolis and its active substances flavonoids showed antibacterial, ${ }^{7)}$ analgesic/anti-inflammatory, ${ }^{7)}$ antioxidant, ${ }^{6}$ prooxidant, ${ }^{8)}$ immunoenchancement, ${ }^{9)}$ antiproliferative activity in cultured human tumor cells ${ }^{10)}$ and antitumor activity in mice. ${ }^{11)}$ Antioxidant activity of flavonoids is based on ability of direct free radicals scavenging or stabilizing the reactive oxygen species (ROS) by interacting with the reactive compound of the radical. Because of the high reactivity of the hydroxyl substituents of the flavonoids, radicals are made inactive. ${ }^{7)}$ ROS in the presence of iron resulted in lipid peroxidation. Some flavonoids are known to chelate iron. ${ }^{7)}$ Flavonoids can also increase the function of the endogenous antioxidant enzyme systems; superoxide dismutase (SOD), catalase (CAT), glutathione peroxidase (GPx), glutathione reductase (GR) and gluthation. ${ }^{12)}$ Furthermore, antioxidant effects may be a result of a combination of radical scavenging and an interaction with enzyme functions.

Genotoxicity of ionizing radiation was studied with different approaches using sensitive methods to measure a single and double strand breaks (SSB, DSB) of DNA; mostly used tests are comet assay for SSB and micronucleus test for DSB.

The aim of this study was to evaluate radioprotective effects of propolis and single flavonoids, caffeic acid, chrysin and naringin in the whole-body irradiated (WBI) mice with two doses of $\gamma$-irradiation using an alkaline comet assay. The efficiency of tested compounds was evaluated on the white blood cells of mice treated preventively and therapeutically. The possible genotoxic effects of all compounds were also assessed on non-irradiated animals.

\section{MATERIALS AND METHODS}

Preparation of Water-Soluble Derivate of Propolis (WSDP) WSDP was prepared by the method described elsewhere. ${ }^{13)}$ Briefly, Croatian propolis from beehives kept at the outskirts of Zagreb, Croatia was extracted with $96 \%$ ethanol, which was filtered and evaporated to dryness in vacuum evaporator. The resultant resinous product was added to a stirred solution of 8\% L-lysine (Sigma Chemie, Deisenhofen, Germany) and freeze-dried to yield the WSDP, a yellow-brown powder.

The chemical profile of propolis from the northern hemisphere, often named as "poplar-type" propolis can be characterized by the three analytical parameters: total flavonol and flavone content, total flavanone and dihydroflavonol content, and total polyphenolics content. According to Popova et al. ${ }^{14)}$ spectrophotometric procedures for quantification of the three main groups of bioactive substances in propolis could be used for quality assessment of different propolis samples, and results of those analyses correlate with biological activ- 
ity, especially in the "poplar-type" of propolis. ${ }^{14)}$ The spectrophotometric assay based on the formation of aluminium chloride complex was applied for quantification of total flavones/flavonols and expressed as quercetin equivalent. ${ }^{14)}$ For the quantification of flavanones and dihydroflavonols propolis, we used 2,4-dinitrophenylhydrazine method. ${ }^{14)}$ Total polyphenolics content was measured by the Folin-Ciocalteu procedure. ${ }^{11)}$ WSDP contains: flavones and flavonols $2.13 \%$, flavanones and dihydroflavonols $9.06 \%$, total flavonoids $11.19 \%$, total polyphenols $70.48 \%$.

WSDP was stored under sterile conditions at $-20^{\circ} \mathrm{C}$ to minimize bacterial contamination. Before use WSDP was dissolved in distilled water.

Preparation of Flavonoids Caffeic acid (CA)-3,4-dihydroxycinnamic acid (Aldrich-Chemie, Milwaukee, WI, U.S.A.), Chrysin-5,7-dihydroxyflavone and Naringin4',5,7-trihydroxyflavanone 7-rhamnoglucoside (Sigma, Germany), were dissolved in distilled water.

Chemicals AET (2-aminoetilizotiourea dihidrobromid; $\mathrm{C}_{3} \mathrm{H}_{9} \mathrm{~N}_{3} \mathrm{Sx} 2 \mathrm{HBr}$; Sigma Chemical Co., U.S.A.) was used as positive control for radioprotection.

Animals Animal studies were carried out according to the guidelines force in Republic of Croatia (Law on the Welfare of Animals, N.N. \#19, 1999) and in compliance to the Guide for the Care and Use of Laboratory Animals, DHHS Publ. \# (NIH) 86-123. Male CBA mice approximately 2 months old, weighing from $22-25 \mathrm{~g}$ from our conventional mouse colony were used. The animals were maintained on a pellet diet and water ad libitum.

Treatment Three independent experiments were performed. In the first experiment mice were treated preventively with test components for three consecutive days. Mice were treated with test compounds intraperitoneally (i.p.) at dose of $100 \mathrm{mg} \mathrm{kg}^{-1}$ body weight and then irradiated with $\gamma$ rays at doses of 4 and $9 \mathrm{~Gy}$. The alkaline comet assay was performed on whole blood samples taken $30 \mathrm{~min}$ after irradiation. In the second experiment mice were irradiated with doses of 4 and $9 \mathrm{~Gy}$ and then treated i.p. for three consecutive days with test components at dose of $100 \mathrm{mg} \mathrm{kg}^{-1}$. The comet assay was performed on whole blood samples on the third day after finishing the treatment. In the third experiment non-irradiated mice were treated with all tested compounds and the comet assay was performed on the third day after finishing the treatment. Appropriate negative controls and positive control group (treated with chemical radioprotector AET) were also selected and handled in the same manner. Experimental groups were composed of 5 mice each and two independent experiments were performed.

Irradiation Whole-body irradiation was performed using a ${ }^{60} \mathrm{Co} \gamma$-ray source (situated at the Ruder Bošković Institute, Zagreb, Croatia). Mice were placed in plexiglas cages and irradiated in groups of five mice simultaneously. The source-to-skin distance was $291 \mathrm{~cm}$ with a dose $0.0233 \mathrm{~Gy} / \mathrm{s}$. Mice were irradiated with a total dose of 4 and $9 \mathrm{~Gy}$; the duration of irradiation was $173 \mathrm{~s}$ and $390 \mathrm{~s}$, respectively.

The Comet Assay The comet assay was carried out under alkaline conditions, as described by Singh et al. ${ }^{15)}$ Two slides per animal were prepared. Agarose gels were prepared on fully frosted slides coated with $1 \%$ and $0.6 \%$ normal melting point (NMP) agarose (Sigma). Peripheral blood samples $(5 \mu \mathrm{l})$ were mixed with $0.5 \%$ low melting point (LMP) agarose (Sigma), placed on the slides and covered with a layer of $0.5 \%$ LMP agarose. The slides were immersed for $2 \mathrm{~h}$ in freshly prepared ice-cold lysis solution $(2.5 \mathrm{M} \mathrm{NaCl}$, $100 \mathrm{~mm} \mathrm{Na} \mathrm{Na}_{2}$ ETA, $10 \mathrm{~mm}$ Tris-HCl, $1 \%$ Na-sarcosinate (Sigma), $\mathrm{pH} 10$ ) with $1 \%$ Triton X-100 (Sigma) and 10\% dimethyl sulfoxide (Kemika). Denaturation and electrophoresis were carried out at $4{ }^{\circ} \mathrm{C}$ under dim light in freshly prepared electrophoresis buffer $\left(300 \mathrm{~mm} \mathrm{NaOH}, 1 \mathrm{~mm} \mathrm{Na} \mathrm{Na}_{2}\right.$ DTA, pH 13.0). After $20 \mathrm{~min}$ of denaturation, the slides were randomly placed in the horizontal gel-electrophoresis tank, facing the anode. Electrophoresis at $25 \mathrm{~V}$ and $300 \mathrm{~mA}$ lasted another $20 \mathrm{~min}$. After electrophoresis, the slides were washed with a neutralization buffer $(0.4 \mathrm{M}$ Tris- $\mathrm{HCl}, \mathrm{pH} 7.5)$ three times at 5 -min intervals. Slides were stained with ethidium bromide $\left(20 \mu \mathrm{g} \mathrm{ml}^{-1}\right)$ and examined using a $250 \times$ magnification fluorescence microscope (Zeiss, Germany) equipped with an excitation filter of $515-560 \mathrm{~nm}$ and a barrier filter of $590 \mathrm{~nm}$. A total of 50 comets per animal were scored (25 from each of two replicate slides). Random fields were selected and at a constant depth of the gel, avoiding the edges, occasional dead cells the comets were captured. Microscope image was transferred to a computer-based image analysis system (Comet Assay II, Perceptive Instruments Ltd.) using a black and white camera. Three main comet parameters were evaluated: tail length (presented in micrometers), tail intensity (DNA\% in comet tail) and tail moment.

Statistical Analysis Statistical analyses were carried out using Statistica 7.0 software (StatSoft, Tulsa, U.S.A.). Each sample was characterized for the extent of DNA damage by considering the mean ( \pm S.D. of the mean), median and range for the comet parameters measured in two experiments. Moreover, cells were classified as either "undamaged" or "damaged" by considering threshold levels indicating the comets with a long-tailed nucleus (LTN), i.e., the length over the 95th percentile of the distribution of the tail lengths among controls. ${ }^{2)}$ In order to normalize distribution and to equalize the variances, a logarithmic transformation of data was applied. Multiple comparisons between groups were done by means of ANOVA on log-transformed data. Post-hoc analysis of differences was done by Scheffé test. Comparisons regarding the frequency of LTN comets were made using non-parametric $\chi^{2}$-test. The level of statistical significance was set at $p<0.05$. The statistical evaluation of leukocyte counts was performed using Student's $t$-test. A difference of $p<0.05$ was considered statistically significant.

\section{RESULTS}

The leukocyte counts in mice treated preventively with WSDP and flavonoids before irradiation with 9 Gy were not significantly disturbed ( $p>0.05, t$-test), although minor differences were observed (Table 1). All three comet parameters measured in mice treated preventively with tested compounds were significantly lower as compared to irradiated negative control $(p<0.05$, Scheffé test). WSDP was found to be the most effective both in terms of tail length and tail moment values as compared to other treatments. WSDP was found to be more effective compared to positive control. Moreover, significantly lower percentage of LTN in mice treated with WSDP (\%) compared to irradiated negative control was recorded $\left(p<0.001 ; \chi^{2}\right.$ test $)$ (Table 1$)$. Inter-group 
Table 1. The Total Leukocyte Number and the Results of Alkaline Comet Assay on Peripheral Blood Leukocytes ${ }^{a)}$

\begin{tabular}{|c|c|c|c|c|c|c|c|c|c|c|c|c|c|c|}
\hline \multirow{3}{*}{ Group } & \multirow{3}{*}{$\begin{array}{l}\text { Leukocytes } \\
\qquad\left(\times 10^{6}\right) \\
X \pm \text { S.E }\end{array}$} & \multicolumn{13}{|c|}{ Comet parameters } \\
\hline & & \multicolumn{5}{|c|}{ Tail length $(\mu \mathrm{m})$} & \multicolumn{4}{|c|}{ Tail intensity (DNA \%) } & \multicolumn{4}{|c|}{ Tail moment } \\
\hline & & Mean \pm S.E. & Median & Min. & Max. & $\%$ LTN & Mean \pm S.E. & Median & Min. & Max. & Mean \pm S.E. & Median & Min. & Max. \\
\hline WSDP & $7.01 \pm 1.10$ & $17.99 \pm 0.27 *$ & 17.31 & 10.9 & 32.69 & $45.6 *$ & $3.25 \pm 0.23 *$ & 2.24 & 0 & 26.86 & $0.46 \pm 0.03 *$ & 0.31 & 0 & 3.27 \\
\hline Caffeic acid & $7.25 \pm 1.54$ & $21.43 \pm 0.31 *$ & 20.51 & 12.18 & 39.74 & 78.8 & $3.12 \pm 0.23 *$ & 1.91 & 0 & 20.33 & $0.51 \pm 0.04^{*}$ & 0.31 & 0 & 3.52 \\
\hline Chrysin & $6.95 \pm 0.86$ & $22.56 \pm 0.35$ & 21.15 & 14.1 & 46.15 & 84.4 & $5.36 \pm 0.27$ & 4.24 & 0 & 23.29 & $0.84 \pm 0.04$ & 0.64 & 0 & 3.52 \\
\hline Naringin & $7.15 \pm 0.66$ & $22.75 \pm 0.39$ & 21.15 & 14.1 & 46.15 & 81.2 & $6.44 \pm 0.35$ & 5.11 & 0 & 31.27 & $0.98 \pm 0.05$ & 0.72 & 0 & 4.81 \\
\hline Positive control $^{b)}$ & $7.45 \pm 1.32$ & $20.11 \pm 0.26^{*}$ & 19.23 & 13.46 & 38.46 & 72.0 & $3.32 \pm 0.24 *$ & 2.41 & 0 & 23.77 & $0.52 \pm 0.04 *$ & 0.36 & 0 & 3.78 \\
\hline Negative control $\left.{ }^{c}\right)$ & $7.86 \pm 0.45$ & $25.42 \pm 0.63$ & 22.44 & 12.18 & 67.95 & 78.0 & $5.96 \pm 0.39$ & 3.66 & 0 & 36.17 & $1.01 \pm 0.07$ & 0.6 & 0 & 6.84 \\
\hline
\end{tabular}

a) Test components were given to mice $(n=5)$ i.p. before irradiation $(9 \mathrm{~Gy})$, daily for 3 consecutive days, and the daily dose contained $100 \mathrm{mg}$ kg ${ }^{-1}$ body weight. 250 comets per group were evaluated. $* p<0.05$ compared with negative control (irradiated mice) (ANOVA). $₫ p<0.001$ compared with negative control (irradiated mice) $\left(\chi^{2}\right.$ test). $b$ ) Positive control-AET $\left(1 \mathrm{~mm} \mathrm{~kg}^{-1}\right)$. c) Negative control—irradiated mice.

Table 2. The Total Leukocyte Number and the Results of Alkaline Comet Assay on Peripheral Blood Leukocytes ${ }^{a}$

\begin{tabular}{|c|c|c|c|c|c|c|c|c|c|c|c|c|c|c|}
\hline \multirow{3}{*}{ Group } & \multirow{3}{*}{$\begin{array}{c}\text { Leukocytes } \\
\left(\times 10^{6} / 1\right) \\
X \pm \text { S.E }\end{array}$} & \multicolumn{13}{|c|}{ Comet parameters } \\
\hline & & \multicolumn{5}{|c|}{ Tail length $(\mu \mathrm{m})$} & \multicolumn{4}{|c|}{ Tail intensity (DNA \%) } & \multicolumn{4}{|c|}{ Tail moment } \\
\hline & & Mean \pm S.E. & Median & Min. & Max. & $\%$ LTN & Mean \pm S.E. & Median & Min. & Max. & Mean \pm S.E. & Median & Min. & Max. \\
\hline WSDP & $0.22 \pm 0.05$ & $14.54 \pm 0.13 *$ & 14.10 & 9.62 & 21.15 & 12.0 & $0.54 \pm 0.09 *$ & 0.11 & 0.00 & 15.42 & $0.07 \pm 0.01 *$ & 0.02 & 0.00 & 1.38 \\
\hline Caffeic acid & $0.31 \pm 0.07$ & $17.83 \pm 0.34 *$ & 16.03 & 11.54 & 36.54 & 40.8 & $2.90 \pm 0.25^{*}$ & 1.37 & 0.00 & 21.82 & $0.44 \pm 0.04 *$ & 0.19 & 0.00 & 3.64 \\
\hline Chrysin & $0.22 \pm 0.05$ & $14.75 \pm 0.13 *$ & 14.74 & 10.26 & 19.87 & 16.4 & $0.83 \pm 0.09 *$ & 0.30 & 0.00 & 11.03 & $0.11 \pm 0.01 *$ & 0.04 & 0.00 & 1.34 \\
\hline Naringin & $0.36 \pm 0.10$ & $14.87 \pm 0.14 *$ & 14.74 & 10.26 & 21.79 & 15.6 & $1.02 \pm 0.11 *$ & 0.48 & 0.00 & 15.86 & $0.14 \pm 0.01 *$ & 0.07 & 0.00 & 1.93 \\
\hline Positive control ${ }^{b)}$ & $0.33 \pm 0.07$ & $14.73 \pm 0.17 *$ & 14.10 & 10.26 & 30.13 & 12.8 & $1.20 \pm 0.13 *$ & 0.50 & 0.00 & 17.62 & $0.16 \pm 0.02 *$ & 0.06 & 0.00 & 1.92 \\
\hline Negative control $^{c)}$ & $0.63 \pm 0.62$ & $20.36 \pm 0.71$ & 16.67 & 10.90 & 87.82 & 49.6 & $4.23 \pm 0.44$ & 1.66 & 0.00 & 46.90 & $0.65 \pm 0.07$ & 0.24 & 0.00 & 7.45 \\
\hline
\end{tabular}

a) Test components were given to mice $(n=5)$ i.p. after irradiation ( $9 \mathrm{~Gy}$ ), daily for 3 consecutive days, and the daily dose contained $100 \mathrm{mg}$ kg ${ }^{-1}$ body weight. 250 comets per group were evaluated. $* p<0.05$ compared with negative control (irradiated mice) (ANOVA). b) Positive control—AET ( $1 \mathrm{~mm} \mathrm{~kg}^{-1}$ ). $\quad c$ ) Negative control—irradiated mice.

Table 3. The Total Leukocyte Number and the Results of Alkaline Comet Assay on Peripheral Blood Leukocytes ${ }^{a)}$

\begin{tabular}{|c|c|c|c|c|c|c|c|c|c|c|c|c|c|c|}
\hline \multirow{3}{*}{ Group } & \multirow{3}{*}{$\begin{array}{l}\text { Leukocytes } \\
\qquad\left(\times 10^{6}\right) \\
X \pm \text { S.E. }\end{array}$} & \multicolumn{13}{|c|}{ Comet parameters } \\
\hline & & \multicolumn{5}{|c|}{ Tail length $(\mu \mathrm{m})$} & \multicolumn{4}{|c|}{ Tail intensity (DNA \%) } & \multicolumn{4}{|c|}{ Tail moment } \\
\hline & & Mean \pm S.E. & Median & Min. & Max. & $\%$ LTN & Mean \pm S.E. & Median & Min. & Max. & Mean \pm S.E. & Median & Min. & Max. \\
\hline WSDP & $7.47 \pm 0.58$ & $16.12 \pm 0.18^{*}$ & 15.38 & 11.54 & 32.05 & $18.0^{\dagger}$ & $3.25 \pm 0.25$ & 1.89 & 0.00 & 25.63 & $0.41 \pm 0.03$ & 0.26 & 0.00 & 2.96 \\
\hline Caffeic acid & $8.52 \pm 1.06$ & $16.36 \pm 0.23 *$ & 15.38 & 10.26 & 36.54 & 22.0 & $3.42 \pm 0.31$ & 1.92 & 0.00 & 44.14 & $0.43 \pm 0.04$ & 0.26 & 0.00 & 3.96 \\
\hline Chrysin & $7.06 \pm 0.55$ & $18.22 \pm 0.23$ & 17.95 & 11.54 & 37.82 & 43.6 & $2.94 \pm 0.24 *$ & 1.76 & 0.00 & 26.04 & $0.43 \pm 0.03$ & 0.56 & 0.00 & 3.67 \\
\hline Naringin & $7.08 \pm 1.22$ & $15.81 \pm 0.23 *$ & 15.38 & 10.26 & 51.92 & $16.8^{\dagger}$ & $2.72 \pm 0.28 *$ & 1.14 & 0.00 & 37.00 & $0.43 \pm 0.04$ & 0.16 & 0.00 & 9.89 \\
\hline Positive control $^{b)}$ & $6.33 \pm 1.14$ & $18.47 \pm 0.22$ & 18.27 & 10.26 & 31.41 & 50.0 & $3.21 \pm 0.22$ & 2.03 & 0.00 & 24.41 & $0.46 \pm 0.03$ & 0.31 & 0.00 & 3.29 \\
\hline Negative control ${ }^{c}$ ) & $7.69 \pm 0.92$ & $18.57 \pm 0.40$ & 16.67 & 12.18 & 54.49 & 31.2 & $3.44 \pm 0.28$ & 1.99 & 0.00 & 35.62 & $0.49 \pm 0.04$ & 0.26 & 0.00 & 6.62 \\
\hline
\end{tabular}

a) Test components were given to mice $(n=5)$ i.p. before irradiation $(4 \mathrm{~Gy})$, daily for 3 consecutive days, and the daily dose contained $100 \mathrm{mg} \mathrm{kg}^{-1}$ body weight. 250 comets per group were evaluated. $* p<0.05$ compared with negative control (irradiated mice) (ANOVA). $\dagger p<0.05$ compared with negative control (irradiated mice) $\left(\chi^{2}\right.$ test). $b$ ) Positive control-AET $\left(1 \mathrm{~mm} \mathrm{~kg}^{-1}\right)$. c) Negative control-irradiated mice.

comparisons revealed other differences between single groups that are reported in Table 1.

In mice treated with WSDP and flavonoids after irradiation with 9 Gy leukocyte counts were significantly lower as compared to irradiated negative control $(p<0.05, t$-test). Minor inter-group differences were also observed (Table 2). All three comet parameters measured in mice treated with test components after irradiation were significantly lower as compared to irradiated negative control $(p<0.05$, Scheffé test). Among the treatments studied, WSDP was found to be the most effective in terms of all comet parameters evaluated compared to positive and negative control. In addition, the lowest percentage of LTN was recorded in mice treated with WSDP $(\%)$ compared to irradiated negative control $(p<0.05$; $\chi^{2}$ test) (Table 2). The inter-group differences were also observed and thay are reported in Table 2.

The leukocyte counts in mice treated with WSDP and flavonoids before irradiation with 4 Gy were not significantly disturbed ( $p>0.05, t$-test), although minor differences were observed (Table 3). Tail length measured in mice treated with WSDP, CA and naringin were significantly lower as compared to irradiated negative control ( $p<0.05$, Scheffé test). Naringin was found to be the most effective as compared to other treatments. Moreover, significantly lower percentage of LTN (\%) in mice treated with WSDP and naringin as compared to irradiated negative control was recorded $(p<0.05$; $\chi^{2}$ test) (Table 3 ). Tail intensity in mice treated with chrysin and naringin were significantly lower as compared to irradi- 
Table 4. The Total Leukocyte Number and the Results of Alkaline Comet Assay on Peripheral Blood Leukocytes ${ }^{a)}$

\begin{tabular}{|c|c|c|c|c|c|c|c|c|c|c|c|c|c|c|}
\hline \multirow{3}{*}{ Group } & \multirow{3}{*}{$\begin{array}{c}\text { Leukocytes } \\
\left(\times 10^{6} / 1\right) \\
X \pm \text { S.E. }\end{array}$} & \multicolumn{13}{|c|}{ Comet parameters } \\
\hline & & \multicolumn{5}{|c|}{ Tail length $(\mu \mathrm{m})$} & \multicolumn{4}{|c|}{ Tail intensity } & \multicolumn{4}{|c|}{ Tail moment } \\
\hline & & Mean \pm S.E. & Median & Min. & Max. & $\%$ LTN & Mean \pm S.E. & Median & Min. & Max. & Mean \pm S.E. & Median & Min. & Max. \\
\hline WSDP & $2.02 \pm 0.53$ & $15.94 \pm 0.36 *$ & 14.10 & 10.90 & 50.00 & $30.5^{\dagger}$ & $3.07 \pm 0.31 *$ & 1.06 & 0.00 & 29.99 & $0.42 \pm 0.05^{*}$ & 0.14 & 0.00 & 6.17 \\
\hline Caffeic acid & $1.16 \pm 0.29$ & $17.84 \pm 0.40$ & 16.03 & 10.26 & 47.43 & 44.0 & $4.54 \pm 0.44$ & 2.18 & 0.00 & 42.30 & $0.66 \pm 0.07 *$ & 0.27 & 0.00 & 7.59 \\
\hline Chrysin & $0.77 \pm 0.12$ & $15.66 \pm 0.43 *$ & 13.46 & 9.62 & 52.56 & $28.0^{\dagger}$ & $2.59 \pm 0.33 *$ & 0.59 & 0.00 & 31.24 & $0.38 \pm 0.05^{*}$ & 0.07 & 0.00 & 5.69 \\
\hline Naringin & $0.63 \pm 0.12$ & $15.93 \pm 0.48 *$ & 13.46 & 9.62 & 47.43 & $32.0^{\dagger}$ & $3.35 \pm 0.41 *$ & 0.66 & 0.00 & 39.16 & $0.50 \pm 0.07 *$ & 0.08 & 0.00 & 8.12 \\
\hline Positive control ${ }^{b)}$ & $1.28 \pm 0.21$ & $18.38 \pm 0.54$ & 15.38 & 10.26 & 52.56 & 50.1 & $4.75 \pm 0.50$ & 1.44 & 0.00 & 47.40 & $0.79 \pm 0.09$ & 0.19 & 0.00 & 8.34 \\
\hline Negative control $^{c)}$ & $1.09 \pm 0.12$ & $18.01 \pm 0.53$ & 15.06 & 10.26 & 53.85 & 45.0 & $4.62 \pm 0.59$ & 1.34 & 0.00 & 49.84 & $0.78 \pm 0.12$ & 0.17 & 0.00 & 12.46 \\
\hline
\end{tabular}

a) Test components were given to mice $(n=5)$ i.p. after irradiation ( $4 \mathrm{~Gy})$, daily for 3 consecutive days, and the daily dose contained $100 \mathrm{mg} \mathrm{kg}^{-1}$ body weight. 250 comets per group were evaluated. $* p<0.05$ compared with negative control (irradiated mice) (ANOVA). $\uparrow p<0.05$ compared with negative control (irradiated mice) $\left(\chi^{2}\right.$ test). $b$ ) Positive control-AET $\left(1 \mathrm{~mm} \mathrm{~kg}^{-1}\right)$. c) Negative control—irradiated mice.

Table 5. The Total Leukocyte Number and the Results of Alkaline Comet Assay on Peripheral Blood Leukocytes ${ }^{a)}$

\begin{tabular}{|c|c|c|c|c|c|c|c|c|c|c|c|c|c|c|}
\hline \multirow{3}{*}{ Group } & \multirow{3}{*}{$\begin{array}{c}\text { Leukocytes } \\
\left.\qquad \times 10^{6} / 1\right) \\
X \pm \text { S.E. }\end{array}$} & \multicolumn{13}{|c|}{ Comet parameters } \\
\hline & & \multicolumn{5}{|c|}{ Tail length $(\mu \mathrm{m})$} & \multicolumn{4}{|c|}{ Tail intensity (DNA \%) } & \multicolumn{4}{|c|}{ Tail moment } \\
\hline & & Mean \pm S.E. & Median & Min. & Max. & $\%$ LTN & Mean \pm S.E. & Median & Min. & Max. & Mean \pm S.E. & Median & Min. & Max. \\
\hline WSDP & $8.03 \pm 0.66$ & $13.65 \pm 0.18$ & 12.82 & 10.26 & 42.31 & 16.92 & $1.55 \pm 0.14$ & 0.65 & 0.00 & 14.37 & $0.19 \pm 0.02$ & 0.08 & 0.00 & 1.66 \\
\hline Caffeic acid & $8.13 \pm 1.00$ & $14.39 \pm 0.19$ & 13.46 & 10.26 & 32.69 & 13.08 & $2.90 \pm 0.31$ & 1.05 & 0.00 & 31.47 & $0.36 \pm 0.04$ & 0.13 & 0.00 & 3.91 \\
\hline Chrysin & $6.53 \pm 1.00$ & $15.06 \pm 0.22$ & 14.10 & 10.90 & 44.23 & 17.69 & $2.55 \pm 0.27$ & 0.95 & 0.00 & 34.43 & $0.33 \pm 0.03$ & 0.13 & 0.00 & 4.41 \\
\hline Naringin & $7.20 \pm 0.77$ & $14.60 \pm 0.27$ & 13.46 & 9.62 & 39.74 & 15.90 & $2.30 \pm 0.30$ & 0.47 & 0.00 & 42.47 & $0.30 \pm 0.04$ & 0.06 & 0.00 & 4.90 \\
\hline Positive control $^{b)}$ & $9.63 \pm 1.28$ & $15.38 \pm 0.21$ & 14.74 & 10.90 & 31.41 & 12.56 & $3.00 \pm 0.31$ & 0.97 & 0.00 & 32.08 & $0.39 \pm 0.04$ & 0.12 & 0.00 & 3.70 \\
\hline Negative control $^{c)}$ & $9.84 \pm 0.98$ & $14.11 \pm 0.18$ & 13.46 & 10.26 & 28.85 & 11.54 & $2.19 \pm 0.23$ & 0.72 & 0.00 & 30.25 & $0.27 \pm 0.03$ & 0.09 & 0.00 & 4.07 \\
\hline
\end{tabular}

a) Test components were given to mice $(n=5)$ i.p. daily for 3 consecutive days, and the daily dose contained $100 \mathrm{mg} \mathrm{kg}^{-1}$ body weight. 250 comets per group were evaluated. b) Positive control-AET $\left(1 \mathrm{~mm} \mathrm{~kg}^{-1}\right)$. c) Negative control—non-irradiated mice.

ated negative control $(p<0.05$, Scheffé test). In mice treated with naringin we observed significantly lower tail moment values as compared to irradiated negative control $(p<0.05$, Scheffé test). The inter-group comparisons revealed other differences between single groups that are reported in Table 3 .

The leukocyte counts in mice treated with WSDP and flavonoids after irradiation with $4 \mathrm{~Gy}$ were not significantly disturbed ( $p>0.05, t$-test), although minor differences were observed (Table 4). Tail length measured in mice treated with WSDP, chrysin and naringin were significantly lower as compared to irradiated negative control $(p<0.05$, Scheffé test). Naringin was found to be the most effective as compared to other treatments. Moreover, significantly lower percentage of LTN (\%) in mice treated with WSDP and naringin as compared to irradiated negative control was recorded $(p<0.05$; $\chi^{2}$ test) (Table 4$)$. Inter-group comparisons revealed other differences between single groups that are reported in Table 4.

Based on the results obtained, neither WSDP nor flavonoids tested were cyto/genotoxic to non-irradiated mice as measured with comet assay. There were some, but not significant inter-group differences observed (Table 5).

\section{DISCUSSION}

The main finding of the present study is that WSDP and related flavonoids possess promising radioprotective effects, comparable to well-established chemical radioprotector AET. Mice used in our study were exposed to dose of 9 and $4 \mathrm{~Gy}$, of $\gamma$-radiation respectively. Previous studies on X-irradiated mice confirmed the ability of AET $\left(300 \mathrm{mg} \mathrm{kg}^{-1}\right)$ to prolong the survival rate in dose range of $8-11 \mathrm{~Gy} .{ }^{17)}$ Although in these experiments lower dose of AET was used as positive control, the radioprotective effects were still observed, both in terms of cytoprotection and the protection against primary DNA damage. Based on these results, natural compounds WSDP and related flavonoids were highly effective in cytoprotection. They did not induce significant genotoxicity to white blood cells of non-irradiated mice, but offer a quite measurable protection against DNA damage caused by ionizing radiation. The alkaline comet assay employed in this study is capable of the detection of SSBs and the alkali labile sites present in DNA. Therefore, chemical alterations of nucleic acids, such as breaks of hydrogen bounds, breaks of base-sugar binding, sugar oxidation, break of nucleotide strand and release of terminal phosphates caused by reaction of free radicals can be sensitively detected by means of the technique used. ${ }^{2,18)}$ The exact mechanism of action in protecting mice from lethal effects of acute WBI by propolis and related flavonoids is not known. These results indicate that preventive treatment of irradiated mice with WSDP and related flavonoids significantly decreased the levels of primary DNA damage in their white blood cells and increased life span of mice, ${ }^{19)}$ as compared to untreated animals.

In humans WSDP and related flavonoids are typically taken orally. However, in our experience, oral application by gastric canula is much more stressful than i.p. application. Since the comet assay used in these studies has shown to be stress sensitive we have found that i.p. application of the 
components is more suitable for mice than p.o. According to Dimov et $a .^{20)}$ development of water-soluble fractions and forms of natural propolis enable the application of propolis parenterally, thus providing better resorption of the compound which is believed to improve its medical efficacy. It is known that the polyphenols are absorbed by passive diffusion. For this to occur, the glycosylated polyphenols need to be converted to aglicone by glycosides in the food or in gastrointestinal mucosa, and colon microflora, respectively. Flavonoids in nature (in plants) are glycosylated polyphenols which honey bee convert by enzymes from their mandibular glands in aglicones which is shown to be easily absorbed in the intestines. Moreover, WSDP consist of solved phenolic acids and their esters such as CAPE (23\%). Ester components much easily cross through cell membrane than phenolic acid. ${ }^{20)}$

Several studies have confirmed the role of flavonoids in the deactivation of the free radicals, ${ }^{6,8)}$ but very few data have been published considering the effect of propolis and its polyphenolic compounds in the protection from the wholebody irradiation. ${ }^{20)}$

Flavonoids posses antioxidant activity based on ability of direct free radicals scavenging, or stabilizing the ROS by reacting with the reactive compound of the radicals. Because of the high reactivity of the hydroxyl substituents of the flavonoids, radicals are made inactive. ${ }^{8)}$ Flavonoids can also increase the function of the endogenous antioxidant enzyme systems. Furthermore, antioxidant effects may be a result of a combination of radical scavenging and an interaction with enzyme functions. ${ }^{8)}$ Our results strongly support these observations. Therefore, stable doses of WSDP and flavonoids present in an organism prior to the irradiation could possibly diminish the frequency of DNA-strand breakage or stimulate the repair processes with consequent decrease of the frequency of DSBs (considered to be the primary lesion involved in cellular death). It is also possible that both WSDP and flavonoid components stimulate other intracellular enzyme systems capable of protecting cells against free radicals and DNA damage. ${ }^{22}$ Endogenous and exogenous oxidative challenges have endowed living cells of aerobic organisms with sophisticated antioxidant systems (enzymatic and nonenzymatic) to regulate oxidative stress. The antioxidant defense system of living organisms can be subdivided into enzymatic antioxidants, such as superoxide dismutase (SOD), catalase (CAT), and glutathione peroxidase (GPX), and nonenzymatic antioxidants systems, respectively. The nonenzymatic antioxidant systems are mainly substances of low molecular weight, such as vitamins $\mathrm{C}$ and $\mathrm{E}$, urate, retinyl esters, $\beta$-carotene, glutathione (GSH), etc. Reduced glutathione $(\mathrm{GSH})$ is an endogenous antioxidant that acts as a first line defense system against prooxidant status. It has been found that propolis and its polyphenolic/flavonoid components increased activities of superoxide dismutase (SOD), catalase (CAT), glutathione peroxidase (GPx), glutathione reductase (GR), and glutathione (GSH). ${ }^{22-24)}$ Nonenzymatic repair mechanisms of WSDP and related flavonoids scavenging hydrated electrons, oxidizing hydroxyl radical adducts of dGMP, dAMP, dCMP and others thereby protecting DNA from hydrated electron attack. ${ }^{25,26)}$ Activation of possible repair enzymes by WSDP and related flavonoids include induction of DNA repair enzymes (8-oxoguanine-DNA glycosy- lase 1, apurinic/apyrimidinic endonuclease and DNA polymerase beta). ${ }^{27)}$ Authors also reported that flavonoids could augment the "antioxidant status" through the hemeoxygenase-1, mitochondrial superoxide dismutase and the regulatory subunit of $\gamma$-glutamyl-cysteinyl synthetase. ${ }^{28)}$

Radioprotective properties of propolis extract against DNA damage induced by dose depending $\gamma$-irradiation $(0.25-5 \mathrm{~Gy})$ were studied using cytogenetic analysis in vitro. ${ }^{29)}$ A significant decrease in the radiation-induced chromosome aberrations has been observed for high doses, indicating possible dose dependence in the radioprotective effects on DNA. In these in vivo studies the radiation doses applied were 9 or $4 \mathrm{~Gy}$. It is reasonable to assume that after irradiation with $9 \mathrm{~Gy}$ a lot of single and double strand breaks, as well as base modifications and oxidative damage in the damaged blood cells were induced. It was assumed that the amount of the lesions inflicted directly and/or indirectly in leucocyte DNA of mice will be relatively high in this time point and that propolis and related flavonoids can react with hydrated electron in repair process protecting DNA against induced DNA damage. Although the repair processes tend to diminish the primary induced DNA lesions in a few minutes $^{30)}$ to a couple of hours after infliction, ${ }^{15)}$ some of the damaged sites have to be repaired using more complex repair mechanisms (including those that generate additional DNA strand breaks). Therefore, the alkaline comet assay performed on the third day after irradiation reflects the levels of DNA damage that result both from the repair and from the infliction of new damage(s) caused by repair mechanisms itself.

On the third day after lethal WBI number of the leukocytes in mice was reduced. Such a low number of WBI per animal originated from the extreme disturbance of haematopoiesis; this topic is discussed by Oršolić et al., ${ }^{19)}$ where authors described fully the reasons of hematopoietic failure after irradiation with $9 \mathrm{~Gy}$; the pathological cellular emptiness of bone marrow and spleen in mice which died on day 5 after lethal WBI indicated that their deaths could have been prescribed to the hemopoietic syndrome. It was recognized earlier that the exposure of mammals to ionizing radiation causes the development of a complex, dose dependent series of potentially fatal physiologic and morphologic changes, known as hematopoietic syndrome. ${ }^{22)}$ It occurs at dose $2.5-8 \mathrm{~Gy}$ and is manifested by hematopoietic stem cell depletion, and ultimately by depletion of mature hemopoietic and immune cells. Therefore, the majority of white blood cells measured by the alkaline comet assay in our study could be considered as undeveloped and undamaged, since highly damaged cells died by means of apoptosis/necrosis and were obviously destroyed. In mice irradiated with $4 \mathrm{~Gy}$ preventively treated with test components all but chrysin reduced tail length of leucocytes indicating protective effect of test components. Test components given after irradiation also reduced the DNA damage of leucocytes; tail length for WSDP was 15.94 $v s$. positive and negative control $(18.38,18.01)$, respectively. All in all, results of comet assay implied that WSDP and related polyphenols could be successfully and safety used in protection from ionising irradiation.

In conclusion, results obtained with $\gamma$-irradiated mice pretreated for three consecutive days with WSDP and flavonoids indicate that these compounds could be considered effective 
non-toxic radioprotectors. Further studies are needed to implement the use of natural compounds in clinical protection against ionizing radiation.

\section{REFERENCES}

1) Karbownik M., Reiter J. R., Proc. Soc. Exp. Biol. Med., 225, 9-22 (2000).

2) Olive P. L., Int. J. Radiat. Biol., 75, 395-405 (1999).

3) Little J. B., Carcinogenesis, 21, 397-404 (2000).

4) Grdina D. J., Sigdestad C. P., Drug Metab. Rev., 20, $13-42$ (1989).

5) Bankova V., J. Ethnopharmacol., 100, 114-117 (2005).

6) Kumazawa S. H., Yoneda M., Shibata I., Kanaeda J., Hamasaka T., Nakayama T. S., Chem. Pharm. Bull., 51, 740-742 (2003).

7) Nijveldt R. J., van Nood E., van Hoorn D. E., Boelens P. G., van Norren K., van Leeuwen P. A., Am. J. Clin. Nutr., 74, 418-425 (2001)

8) Galati G., O’Brien P. J., Free Radic. Biol. Med., 37, 287-303 (2004).

9) Orsolic N., Horvat Knežević A., Basic I., Mellifera, 2, 29-46 (2002).

10) Chen Ch., Weng M., Wu Ch., Lin J., CAM, 1, 175-185 (2004).

11) El-khawaga O. A., Salem T. A., Elshal M. F., Clin. Chim. Acta, 338, $11-16$ (2003).

12) Russo A., Acquaviva R., Campisi A., Sorrenti V., Di Giacomo C., Virgata G., Barcellona M. L., Vanella A., Cell. Biol. Toxicol., 16, 91-98 (2000).

13) Orsolic N., Basic I., J. Ethnopharmacol., 84, 265-273 (2003).

14) Popova M., Bankova V., Naydensky C. H., Tsvetkova I., Kujumgiev A., Macedonian Pharm. Bull., 50, 9-14 (2004).

15) Singh N. P., McCoy M. T., Tice R. R., Schneider L. L., Exp. Cell Res., $175184-191$ (1988).

16) Hayashi M., MacGregor J. T., Gatehouse D. G., Adler I. D., Blakey D.
H., Dertinger S. D., Krishna G., Morita T., Russo A., Sutou S., Environ. Mol. Mutagen., 35, 234-252 (2000).

17) Sverdlov A. G., Mozzhukhin A. S., Pavlova L. M., Nikanorova N. G., Radiobiologia, 9, 706-710 (1969).

18) Piperakis S. M., Visvardis E. E., Tassiou A. M., Method Enzymol., 300, 184-194 (1999).

19) Oršolić N., Benković V., Horvat Knežević A., Kopjar N., Kosalec I., Bakmaz M., Mihaljević Ž., Bendelja K., Bašić I., Biol. Pharm. Bull., 30, 946-951 (2007).

20) Dimov V., Ivanovska N., Bankova V., Popov S., Vaccine, 10, 817-823 (1992).

21) Oršolić N., Kosalec I., Bašić I., Biol. Pharm. Bull., 28, 694-700 (2005).

22) Oršolić N., Bašić I., Biomed. Pharmacother., 59, 561-570 (2005).

23) Oršolić N., Bendelja K., Brbot-Šaranović A., Bašić I., Period. Biol., 106, 367-372 (2004).

24) Molina M. F., Sanchez-Reus I., Iglesias I., Benedi J., Biol. Pharm. Bull., 26, 1398-1402 (2003).

25) Zhao C., Shi Y., Lin W., Wang W., Jia Z., Yao S., Fan B., Zheng R., Mutagenesis, 16, 271-275 (2001).

26) Zhao C., Shi Y., Wang W., Jia Z., Yao S., Fan B., Zheng R., Biochem. Pharm., 65, 1967-1971 (2003).

27) Gao K., Henning S. M., Niu Y., Youssefian A. A., Seeram N. P., Xu A., Heber D., J. Nutr. Biochem., 17, 89-95 (2006).

28) Gohil K., Moy R. K., Farzin S., Maguire J. J., Packer L., Free Radic Res., 33, 831-849 (2000).

29) Montoro A., Almonacid M., Serrano J., Saiz M., Barquinero J. F., Barrios L., Verdu G., Perez J., Villaescusa J. I., Radiat. Prot. Dosimetry, 115, 461-464 (2005).

30) Tice R. R., “Environ Mutagen,” ed. by Philips D. H., Venit S., Bios Scientific Publishers, Oxford, 1994, pp. 315-339. 